\title{
Mobile technologies and development in conflict affected North East region of Nigeria: The issues, benefits and challenges
}

\author{
Joseph Wilson \\ University of Maiduguri, Nigeria
}

DOI: 10.30547/worldofmedia.2.2018.4

\begin{abstract}
The North East of Nigeria for almost a decade has been engulfed in a violent conflict as a result of the Boko haram insurgency. The region is endowed with human and natural resources but remains the least developed part of the country due to the devastating Boko Haram conflicts and weak infrastructural base, among others, thus depriving the region of meaningful development. Recently, developments in the region have shifted to resettling displaced people and rebuilding and rehabilitating the zone in the midst of deep poverty, lower level conflicts and high expectations by the population. In all of that, instant communication and information sharing facilitated by mobile technologies remain central. Thus, the paper assesses the availability, quality and use of mobile technologies by various stakeholders in shaping the various situations, influencing and shaping the processes of development amidst the challenges in the region. Observation and interview were the instruments used for this study. The study found that the destroyed mobile facilities which enable phone networks in settlements along major highways in the region, have been reconstructed and mobile signals are available now. It also found that there are enormous benefits of mobile technologies in shaping development in the region but there are some challenges as well. The paper concludes that despite the challenges, the benefits of mobile technology in shaping development in the region is glaring.
\end{abstract}

Corresponding author:

Joseph Wilson, Department of Mass Communication, University of Maiduguri, P.M.B. 1069, Bama Road, Maiduguri, Nigeria.

Email: wilson@unimaid.edu.ng 


\section{Keywords}

Mobile technologies, conflict, insurgency, development, North East Nigeria, social change.

\section{Introduction}

Mobile technologies have a global-wide acceptability. This is evident in the growing number of users of mobile devices and huge subscription in the mobile telephony sector and associated services. The proliferation of mobile phone networks in just a few years, has transformed communications in subSaharan Africa. It has also allowed Africans to leapfrog from the landline stage of development to the digital age (Wilson \& Gapsiso, 2017). Nigeria, like any other country that is mindful of the enormous benefits of information and communication technologies, has embraced these technologies and has incorporated it into their daily endeavors.

Mobile technology has remarkably changed and is still changing the face of communication in Nigeria. Currently, there is hardly any part of Nigeria that has not felt the impact of mobile technology: government, companies, nongovernmental organizations alike have realized the potential of this technology in addressing pressing national challenges. Mobile technology is increasingly making developmental impact in some key sectors, such as education, health, agriculture, banking, governance, security, etc.

Undoubtedly, a mobile phone is the most noticeable and useful device in the mobile industry; it serves a multiplicity of functions - navigational device, Internet access device, instant messaging client, handheld game console, etc. This point has compelled experts to argue that the future of computer technology is mobile technology (computing with wireless networking).

The introduction of mobile technology, specifically the Global System for Mobile Telecommunication, popularly known as GSM in Nigeria in August, 2000 was a defining moment in the history of the country. Prior to the introduction of this important communication technology, Nigeria's telecommunication industry had been monopolised by government-owned Nigeria Telecommunication Limited (NITEL) and characterized by obsolete telecommunication infrastructure, non-availability of telephone lines/epileptic service delivery and inefficiency. For instance, the total available telephone lines in the country before GSM were below 500.000. This was grossly inadequate for the country's huge population (Wilson \& Gapsiso, 2014; Wilson \& Gapsiso, 2017).

More than 15 years into the introduction of mobile phone services in Nigeria, there has been a speedy development of telecommunication infrastructure across 
the country by the several competing operators, such as MTN, Airtel, Etisalat (now 9mobile), Globacom, Multilinks Telkom, Visafone, etc. This growth and competition in the delivery of telecommunication services are spurred by the overwhelming demand for mobile phone services by Nigerians (NCC, 2016).

Nigeria has an estimated over 187 million inhabitants (Worldometers, 2016). In the earlier years when only fixed telephone lines were available in Nigeria, the service was restricted to urban areas. Rural telephony was not available. However, with the introduction of mobile phones, rural areas have been included in the mobile telephony service (Wilson \& Gapsiso, 2014) Currently, mobile networks in Nigeria have the fastest growth on the continent. The penetration of telephones in Nigeria increased from $0.5 \%$ in 1999 to $8 \%$ in 2004. In 2005, there were 16 million telephone subscribers in Nigeria and 18,587,000 mobile phone lines. In the same year, there were $1,223,000$ fixed lines in the country. Mobile phone penetration is rated at 103\% (National bureau of statistics, 2006, Ndukwe, 2005). Odukoya and Nkadi (2008) found that in 2006, there were 31.1 million mobile phone subscribers in Nigeria and at least 15 million subscribers were connected in 2007. In 2011, it is estimated that Nigeria had about 86.2 million mobile phone subscribers (Kombol, 2009). In 2012, Nigeria had the biggest number of mobile phone subscribers in Africa with more than 93 million (BBC News, 2012). Currently, Nigeria is one of the nations that is estimated to reach $100 \%$ mobile phone penetration. Nigeria mobile phone active subscribers stood at 148.74 million at the end of the first quarter of 2016. As at March 2017, the nation had 155 million active mobile phone subscribers (Aksu360, 2017; Ericsson mobility report, 2015; NCC, 2016). These subscribers cut across the regions of the country, including the North East region that is currently affected by violent conflict.

The North East region of Nigeria has not been left out in the mobile technology penetration and adoption. Before the insurgency, the region, like all other regions in the country, enjoyed its share of mobile technology deployment by the major telecommunication companies in Nigeria (MTN, Globacom, Airtel, Etisalat, and Starcomm). From 2009 when the conflict started to date, mobile technology, especially the mobile phone, has remained a key component of the daily lives of people in the North East.

In spite of the violent conflict in the region, mobile technology has remained a vital component of the day to day activities of the people in the region. The crucial place of mobile phone became glaring when in 2013 mobile telephone network was shut down in Borno, Yobe and Adamawa states as a counter insurgency measure. After that President Goodluck Jonathan declared the state of emergency in these three states. The use of Thuraya services at a point was 
also banned by the military in affected states. While the mobile network was restored in Adamawa and Yobe in July, 2013, Borno state was without mobile telephone network for over 6 months (from 17th May, 2013 to 3rd December, 2013). During this period residents of the affected states had to travel several miles to use mobile technology services.

The North East Nigeria occupies one-fourth of the country's landmass of 970,000 sq. $\mathrm{km}$. The zone has a population exceeding 20 million. It is endowed with human and natural resources but remains the least developed part of the country due to poverty, climate change, poor governance, devastating conflicts and weak infrastructural base (AOAV and NWGAV, 2013; Ojeme, 2011). In the last 5 years, the Boko Haram insurgency devastated the zone with thousands of people killed and injured, displaced over three million people and devastated the economic and social base of the region.

Presently, the violent terror level has reduced significantly with the decimation of the insurgents and stability gradually returning to the region, aattention is now focused on reconstructing, resettling and rehabilitating the zone in the midst of deep poverty, lower level conflicts and high expectations by the traumatized population. In all of that, instant communication and information sharing facilitated by mobile technologies remains central. Thus, this paper assesses the issues (availability, quality and use), benefits and challenges of mobile technologies in different shaping processes of development amidst the challenges in the zone. The paper has the following objectives:

- to find out the issues (availability, quality and use) associated with mobile technology shaping development in the North East region of Nigeria;

- to find out the benefits of mobile technology in shaping development in the North East region of Nigeria;

- to find out the challenges of mobile technology shaping development in the North East region of Nigeria.

\section{Literature review}

Mobile technology especially the mobile phone has become a common feature of the modern-day society landscapes. Over the past years, a number of studies (Elangovan \& Aruchelvan, 2013; Kreutzer, 2008; Wilson \& Gapsiso, 2014; Wilson \& Gapsiso, 2017, etc.) have advanced various position on the importance of mobile technologies, specifically mobile communication. For example, Heeks (1999) noted that mobile technology has become an essential infrastructure which connects people from different parts of the world, helps analyse data, transfer information and manage knowledge in order to expand the capability 
of human effort. Lisa (2015) noted that mobile technology has become a global necessity, providing the ability to communicate with the family, business associates, and the access to email, storing data, taking pictures, and other functions. It has become almost a status symbol in addition to the convenience and security that comes from owning. There are several uses of mobile technology in various fields of human endeavours in this age of intelligent machines that are in perpetual communication, creating new networks of knowledge, information and empowerment across the globe.

In developed countries such as Great Britain, France, USA, Germany, South Korea, mobile technology plays a decisive role in their private and professional lives. Thus, placing mobile technology alongside face-to-face communication, e-mail as the most important means of communication. This technology helps them keep in contact with their family and friends. For example, in South Korea, where the mobile technology such as the mobile phone is already by far the most important means of communication, some people are of the view that communicating via mobile phone is more significant than face-toface communication (Life Studies, 2009). Kingston (2016) noted that this technology has emerged as a perfect way for people to stay connected with others and provide the user with a sense of security. In unusual circumstances such as emergency cases mobile technology can help reach victims quickly and may possibly save lives or prevent further danger. Modern mobile phones are capable of Internet access, sending and receiving photos and files, and some are equipped with Global Positioning System (GPS) technology, allowing for use in most locations around the world and allowing the mobile phone to be found or the user located in the emergency spot (Wilson \& Gapsiso, 2017).

Mobile technology has emerged to play significant roles in various development efforts. For example, in education, mobile technology has helped provide educational institutions in teaching and learning. For instance, one of the telecom companies in Nigeria, Etisalat Nigeria, gave a boost education with the launch of Cliqlite Portal, an Internet enabled initiative that offers unlimited access to a wide range of educational materials to support education and learning. It gives both students and parents access to educational materials not just on mobile devices (IT News Africa 2016).

Mobile technology has also been an extremely transformative tool for agriculture. Mobile phones have allowed farmers to gain access to global market, extension services and important farm inputs (Huffington Post, 2013). For example, a few years ago Nigeria launched the 10 million mobile phone for farmers and an e-wallet agricultural scheme. The scheme has helped farmers access agricultural inputs which were initially diverted by middlemen. 
Mobile phones have been very instrumental to farmers. In Kenya, there is a text messaging platform SokoniSMS64 that uses SMS to transfer exact information about wholesale retails of crops quickly, allowing farmers to negotiate deals with traders and improve upon timing to get crops to the market. There is also the use of mobiles in Tanzania (iCow) to track livestock reproduction, track a cow's individual gestation, feed types, schedules local veterinary contact information and precise market prices of cattle (Huffington Post, 2013).

Another area mobile technology is gaining visibility in developing countries is the health sector, a phenomenon widely known as mHealth. The growth of mobile technologies in the health sector such as text messaging projects, remote monitoring, portable sensors, and mobile phone are changing the way healthcare is delivered globally, with the potential to provide people with some level of access to health resources. Huffington Post (2014) reported that one of the glaring breakthroughs is the potential of mobiles to end life threatening diseases such as malaria through mobile technologies. 'Key malaria fighting tools such as bednets, diagnostic tests, cheap treatment, and reliable drugs are "turbocharged" through SMS mobile phone campaigns'. Text messages are widely used in Sub-Saharan Africa as a means of reaching out to subscribers on Malaria preventive measures. 'Results from text campaigns like these have been phenomenal, increasing bednet use by $12 \%$, translating into 500,000 people sleeping under nets which otherwise may be vulnerable to a deadly mosquito bite' (Huffington Post, 2014). There are other health tips available via text messages for mobile phone subscribers. In Nigeria, a telecommunication company MTN has the mHealth service that disseminates health tips that help improve lifestyle of subscribers. The tips focus on general health cancer, fertility, blood sugar, etc.

Governance, commerce and banking are other areas that mobile technology is increasingly covering nowadays. Governments around the world have appropriated mobile technology in the affairs of governance. Communication and sharing information are key components that drive government activities. For example, Nigeria's telecommunication company Globalcom has supported civil servant in Nigeria with special SIM cards that allow communication and speedy sharing of information among civil servants at almost no cost. Political process has been supported by mobile technologies in areas of voter education, campaigns, citizen mobilization, etc. Nigeria 2015 presidential election was highly supported by mobile technology: a handheld card reader for verifying voters was used extensively by observers and party agents to keep track of the event and report the news to their supervisors. After the election the incumbent president, Dr. Goodluck Jonathan, conceded defeat and congratulated the 
winner Mohammadu Buhari through a phone call (Wilson et al., 2016). Another Nigerian example is related to an SMS mobile platform called 'Shine your Eyes' which allows anyone to send a free SMS with the name of the candidate or representative and receive the basic track record of such a candidate as an answer. Also, a mobile application Roveda 2.0 allows Nigerians notify power cuts, riot or any other event capable of disrupting voting process. There is the whistle blower policy that is supported by mobile technologies. The federal government of Nigeria has created a text messaging platform or contact line, which enables Nigerians with authentic information on possible violation and misconduct inform government (The Nation, 2016).

Commerce and banking have greatly been transformed by mobile technologies. Huffington Post (2014) mentions 2012 report by the World Bank, according to which more than 2.5 billion people are without access to their bank account. Mobile technologies, specifically the mobile phone, is helping change this statistic. Presently, most developing countries, especially in Africa millions of people use basic phone services to transfer money, take out insurance policies, purchase air time, pay bills and collect payments from government and agencies. In Nigeria, Globacom is supporting the federal government cashless payment solution, known as the mCash - a mobile supported payment system that allows sellers or merchants to collect their money from buyers electronically (Guardian, 2016).

Mobile technology is also contributing in area of security. The use of emergency notification systems offers services that can send emergency messages to cell phones via text messages, e-mail accounts, and instant message accounts. This system helps security agencies respond to distress call from citizens. Use of walkie-talkie by security agencies contribute greatly to meeting the communication and information sharing needs of security agencies (Peter \& Jacob, 2012). GPS-enabled devices also help citizens signal for help when emergency situations arise and to track stolen properties that GPS enabled.

Undoubtfully, Nigeria is harnessing mobile technology in the various areas discussed above. Cistematix (2011) noted that the reliance on mobile technology influences financial services, education transportation and logistics, emergency health service, entertainment and information and work related. The reliance on mobile technology is an indication that the technology is available. According to Okonji (2017), the increasing rate of mobile technology subscription services in Africa, especially in Nigeria, proves that mobile services will drive digital transformation in Africa in the next few years. Access and availability have been the driving for the penetration of the technology in African societies. Mobile technology has emerged the platform of choice for creating, distributing and 
consuming innovative digital solutions as services in Africa (Okonji, 2016). Mobile technologies are used even among the poorest farmers and rural dwellers in Africa where provided network is available.

Quality of mobile technology has been improving. According to Okonji (2016), mobile technology subscribers are increasingly migrating to mobile broadband services driven by network rollouts and mobile operator device and data strategies. Mobile broadband connections accounted for a quarter of total connections at the end of 2015, but it is expected to rise in two-thirds by 2020 . The 4G service rollout is gaining traction, and by mid-2016, there were 72 live Long Term Evolution (LTE) technology networks in 32 countries across Africa, half of which were launched in the last two years. In Nigeria, MTN, Globacom, Airtel have all rolled out the 4G LTE mobile service, giving Nigerians the standard quality in terms of mobile technology (Nigerian Bulletin, 2016; Okunola, 2016). Some experts have even argued the quality provided by the companies is even been underutilized (Nigerian Muse, 2012).

While there are several benefits in the use of mobile technologies for development, there are also challenges, especially in developing countries. According to Wilson and Gapsiso (2014), developing countries are still struggling with the issue of access. There are still some Nigerians that do not have access to mobile phone services, especially in the rural areas. There are also challenges of cost of acquiring and maintaining a mobile phone. Tariffs are still very high in Nigeria and several services offered by the operators are still expensive. These challenges have not deterred users. Subscribers increase daily worldwide.

\section{Theoretical framework}

The paper adopts the technological determinism theory. In 1962, Marshall McLuhan explained the main ideas of technological determinism theory-media technology or channels of communication shape the way individuals in the society think, feel, act, and the way society operates as it moves from one technological age to another. McLuhan promotes the position that channels of communication or technologies bring change in family life, workplaces, schools, friendship, religion, recreation and sees every new form of media. The presumption of this theory is that a society's technology spurs the development of its social structure. The theory seeks to present media technology as a key mover of social change. It is an approach that identifies technology or technological advances as central causal element in processes of social change (Griffin 1997; Wood, 1997). These technologies extend the society's reach, increase efficiency and filter or organize and interpret social existence. The theory places technology as a key driving force in society and promoting idea that technological development 
determines social change (changes the way people think and interact with others).

Situating the mobile technology in this theory places it as communication technology that has changed the way the society does a lot of things. Mobile technology is everywhere, accessible to most people and has set-off a new way of communicating and sharing information for development purposes. Mobile phones have influenced communication, entertainment, information access. People use their mobiles for entertainment and as a source of information (Techno Culture, 2009; Wilson \& Gapsiso, 2017). The impact of mobile technology has reached a point that is described as a necessity in everyday existence of the modern society.

Another relevant theory is the diffusion of innovations. The diffusion of innovations is a theory of how, why, and at what rate new ideas and technologies spread through cultures. Everett Rogers introduced this theory in his 1962 book Diffusion of innovations. He defines diffusion as 'the process by which an innovation is communicated through certain channels over time, among the members of a social system'. The key elements in diffusion research are: the innovation, types of communication channels, time or rate of adoption, and the social system which frames the innovation decision process (Rogers, 2003).

There are three types of innovation-decisions within diffusion of innovations. An individual or an organization/social system aliens with a type of decision on whether an innovation is adopted/rejected. The three types of innovationdecisions are: optional innovation-decisions, collective innovation-decisions, authority innovation-decisions. Optional innovation-decision is made by an individual who is in some way distinguished from others in a social system. Collective innovation-decision is made collectively by all individuals of a social system. Authority innovation-decision is made for the entire social system by a few individuals in positions of influence or power. In the context of this paper the decisions are made by the federal government through INEC and other stakeholders such as civil society organization which creates ICT platforms to enable citizens participate in election discussions.

Diffusion of an innovation occurs through a five-step process. Rogers (2003) categorizes the five stages (steps) as: awareness, interest, evaluation, trial, and adoption. He notes that an individual might reject an innovation at any time during or after the adoption process. Rogers subsequently changed the terminology of the five stages to: knowledge, persuasion, decision, implementation, and confirmation.

Knowledge: In this stage the individual is first exposed to an innovation but lacks information about the innovation. It should be noted that at this stage or 
process, the individual has not been inspired to find more information about the innovation. Nigeria has passed this stage, considering the huge number of users of mobile technology, which is an indication that there is a significant level of knowledge in respect of mobile technology among Nigerians.

Persuasion: In this stage the individual is interested in the innovation and actively seeks information/detail about the innovation. Mobile technology for development in Nigeria has gone beyond this stage. The introduction of an information technology policy by the Nigerian government and the willingness and acceptability of mHealth, mobile money, mCash indicate that mobile technology has been accepted.

Decision: In this stage the individual takes the concept of the innovation and weighs the advantages/disadvantages of using the innovation and decide whether to adopt or reject the innovation. Due to the individualistic nature of this stage Rogers' notes that it is the most difficult stage to acquire empirical evidence (Rogers, 2003). Mobile technology has been adopted for the purpose of agriculture, banking, education, etc. in Nigeria.

Implementation: In this stage the individual employs the innovation on a varying degree depending on the situation. During this stage the individual determines the usefulness of the innovation and may search for further information about it. Nigeria is at this stage of implementation. This is evident in the deployment of mobile technology facilities for development purposes (governance, agriculture, health among others) and the use mobile technology platforms by citizens.

Confirmation: In this stage the individual finalizes their decision to continue using the innovation and may use the innovation to its fullest potential. Nigeria is gradually getting to this stage. For example, 2015 general election showcased a massive deployment of mobile technology (mobile phones, electronic voter cards). In agriculture, farmers have adopted the use of a mobile phone and e-wallet system for easy access to farm inputs.

Diffusion theory argues that adoption of new technology and innovation starts with enthusiastic innovators and early-adopters and then moves to use by the early and late-majority when the innovation is better supported and more reliable (Rogers, 2003). Comparatively, one could argue that Nigeria falls among the late majority, especially when compared to what obtains in developed countries and looking back at when the nation began enjoying the deployment of mobile ICT in the 1960s (Wilson \& Gapsiso, 2014). The expectation is that Nigeria would have been among the leading nations in terms of mobile technology deployment for development. However, it is making strides in the African continent considering the number of subscribers of mobile technology such as mobile phone. 


\section{Method}

Observation and interview were the instruments used for this work. Observation as a method of data collection and analysis enables the researcher to gather data across perspectives, time and in the phenomenon's natural setting (Babbie, 1986; Patton, 2002). According to Norskov and Rask (2011), observation method may reveal implicit problems and offer important insight into issues and provide information about informal aspects of interactions and relations which can be difficult to obtain through other methods. Observation and interview covered issue relating to mobile network availability in area badly affected by the insurgent's activities in Borno state. The observation period was between February and May, 2017 in Borno state: (Maiduguri, Settlement in Konduga, local government areas along Maiduguri/Damaturi/Potiskum road, Benishek in Kaga LGA). The routes have a massive concentration of government reconstruction, rehabilitation and resettlement activities. The interviewees were purposively selected based on their experiences in the affected areas during official work duties in Borno state and their familiarity with development projects (rehabilitation, reconstruction and resettlement). 10 respondents were interviewed at various times between February and June, 2017. They include two government officials, 2 journalists, 4 aid workers (NGO workers), 2 security personnel and 1 information and communication technology expert/Primary Health Care supervisor.

\section{Findings and discussion \\ The issues associated with mobile technology shaping development in the North East region of Nigeria}

There is an obvious issue associated with the mobile technology in the region, especially Borno state that is worst affected by the violent conflict. Observation showed that mobile phone networks are now available in settlements along Maiduguri/Damaturu/Potiskum highways. At some points at the peak of the insurgents' attacks, the telecommunication facilities along the highways were destroyed. Only a few towns like Beneshek and Auno had mobile phone network in Borno state axis. Hence, it can be said that some level of mobile technology is available, especially the mobile phone network but the coverage is not as wide as it used to be before the destruction of telecommunication facilities by the insurgents. It was also observed that the 4G LTE network quality available in the Capital city of Maiduguri has not been extended to these areas.

It was observed that the states in the North East, such as Bauchi, Gombe, Taraba and parts of Adamawa that were not seriously affected by the insurgency have not experienced a drop in telecommunication quality, rather they have 
moved on in terms of utilizing the technology for purposes of communication sharing, business transactions, etc. Towns in the north of Adamawa state, such as Mubi, Michika, Bazza, Madagali have their telecommunication services restored to normalcy and being used by subscribers for various developmental purposes, especially communication, information sharing and business transactions.

Respondents pointed out that most of the major towns in the southern part of Borno state (Biu, Shaffa, KwayaKusar, Askira, Shani) have telecommunication services and subscribers use these services with a fairly good quality. However, the northern part of Borno state does not have any telecommunication service. Towns bordering Cameroun, Chad and Niger use telecommunication services of these countries. One of the respondents (the government official) noted that most telecommunication facilities in the northern part of Borno have been destroyed by the insurgents, thus making access to mobile technology difficult or impossible for the ordinary people. The respondent pointed out that it would take a long time for the facilities to be rebuilt, especially those in the rural areas because the telecommunication companies would consider profitability of their investments. The user capacity in such rural areas may not generate the needed profit for the companies. 'People do not spend much on communication and thus the companies may be reluctant to fix or rebuild such facilities in the shortest possible time. People are more concerned about shelter, food and sustainable means of livelihood'. The issues of access of mobile technology in the affected areas, especially in Borno state, is predominantly about availability of facilities. Nevertheless, mobile technology is accessible in Maiduguri, the capital city and other towns in the southern part of the state.

On the issues of quality, the respondent noted that the most important goal at the moment is to rebuild the destroyed facilities so as the affected areas would be connected - no one talks about quality when access is a problem. However, the quality of the mobile technology in the capital city, Maiduguri is comparatively good. The major service providers (MTN, Airtel, Etislat (now 9mobile) , and Globacom) are all functional with some of them providing high quality 4G LTE service, which is driving e-banking, mHealth, e-governance, e-learning activities in the state.

In the area of use, mobile technology has remained a significant component of development activities in Borno and other states in the North East Nigeria. The respondent further pointed out that communication and information sharing is one of the major uses of the technology. Two of the respondents (military personnel and government official) specifically noted that mobile technology helped maintain a high-level communication in the area of security coordination 
in the fight against the insurgents and maintaining security in the communities. The use of various mobile communication devices helps in these regards. They noted that individuals have provided security reports on impending or planned attack on communities, which often helps security agencies in preventing such attacks.

Another respondent (ICT expert and Primary Health Care supervisor) noted that mobile technology is contributing greatly in shaping development in the region. The respondent noted that mobile technology is being used in areas of monitoring vaccinators through the GPS to ensure that areas are adequately covered by the vaccinators. It is also used for data gathering and transfer. $\mathrm{He}$ noted the use of open data kit by supervisors in the health sector. He also pointed out the use of e-ticket for distribution of relief materials by aid agencies, making it easy for distribution of relief materials and accountability on the side of the agencies.

\section{The benefits of mobile technology in shaping development in the North East region of Nigeria}

Respondents noted that there are enormous benefits of mobile technology in shaping development in the region. Respondents identified the major and visible benefits of technology such as communication and information sharing on issues that are related to security. For any form of development, the communities should be secured to develop constantly, and the present reconstruction, rehabilitation and resettlement pursue these goals. Respondents pointed out that state and non-state security apparatus deploy the use of mobile technology, such as mobile phone, GPS, Thuraya among others to ensure that security activities are well coordinated so that the government's and NGO's activities can be carried out (construction and reconstruction of infrastructure in affected communities, distribution of relief materials, teaching and learning activities, etc).

Another benefit of mobile technology in the region is facilitating economic activities. E-banking activities, contacting suppliers of goods and services outside the region, mobile money transaction, sale of mobile technology and its associated components such as SIM cards, recharge cards, thus providing employment to the people are some economic benefits of mobile technology in the region.

Respondents also noted that the benefit associated to health and relief services are important in facilitating development through ensuring healthy communities. Mobile phones, ODK and GPS are very vital in ensuring that health service meant for the communities are not neglected or overlooked by stakeholders, as such they use of these platforms to monitor vaccinators to 
ensure that they reach their designated areas and administer vaccines is very vital.

Two of the respondents (government official and ICT expert) noted that the people pressing needs at the moment are shelter, food and means of livelihood. That interestingly the use of e-ticket is of immense benefit to stakeholders responsible for relief materials distribution and services and allows for accountability and non-diversion of materials to the intended recipients.

\section{The challenges of mobile technology shaping development in the North East region of Nigeria}

Respondents noted that there are obvious challenges associated with mobile technology in shaping development in the region. The major one being access challenges for areas or communities where telecommunication facilities have been destroyed. For such areas, it would take some time to benefit from mobile technology, especially the rural areas where investors might be reluctant to rebuild such facilities. For organisations and agencies that rely on more costly mobile technologies such as Thuraya, the cost might be high thus limiting its full utilization. Respondents noted that only an official or two use such a device in a location that does not have the normal telecommunication service. Respondent noted that it would take a while for telecom services to reach some of the affected areas and to have the wide coverage the area enjoyed before the insurgency or terrorist activities. Access and affordability of the technology, according to the respondents would be major hindrances to fully harnessing mobile technology for development in the region.

Another challenge is in area of quality of service. The quality of telecom services goes along the way in ensuring the effective and smooth use of most mobile technology services, such as mobile Internet, mobile transactions, buying and selling via mobile platforms and sometimes as simple as uninterrupted and clear easy communication and information sharing. It was observed that 4G LTE service is reliable and of better or enhanced quality when compared to GSM or $3 G$.

Another major challenge is knowledge and willingness to fully utilize the mobile technology. Some of the mobile technology services require some level of skills to use. Respondents noted that the services such as GPS, ODK mobile money, and electronic banking transaction require a proper level of knowledge and skills to use. One of the respondents noted that even among the aid and health workers not everyone has the necessary skills to use some of the apps and some are reluctant to use them. 


\section{Conclusion}

The North East region has been badly affected by the activities of the insurgents. The destruction of infrastructure has no doubt taken the region backward. For some communities, it is a fresh start as the infrastructure has been totally destroyed. As the government and other stakeholders are working towards rebuilding the affected communities through the reconstruction, rehabilitation and resettlement programme, mobile technology has proven to be instrumental in the ongoing development efforts in the region. At the peak of the insurgency, mobile technology stood out as a means of addressing communication related issues and even beyond. At this point of rebuilding, mobile technology is a vital tool. Despite the challenges, the benefits of mobile technology in shaping development in the region is glaring. Thus, it is recommended that the government and international organizations should support telecommunication companies (the key providers of mobile technology service) to rebuild destroyed facilities and extend services to areas that were not covered in the past so as to enhance the adoption and utilization of mobile technology in the region. The Nigerian Communication Commission had announced in March, 2017 that it would assist in rebuilding telecoms facilities in the North East region (Daily Trust, 2017), this laudable initiative should be vigorously pursued and implemented.

\section{References}

6 ways mobile technology has transformed the world's poor. Huffington Post, $23^{\text {rd }}$ January 2014. Available from: http://www.huffingtonpost.com/claratsao/6w aysmobiletechologyh_b_4054076.html [Accessed 20 ${ }^{\text {th }}$ February 2017].

Active mobile phone subscribers in Nigeria now 155 million. Aksu360, 20 $0^{\text {th }}$ March 2017. Available from: www.aksu360.blogspot.co.ke/2017/03/activemobile-phone-subscribers-in.html? $\mathrm{m}=1$ [Accessed 20th April 2017].

CHEIJINA, N. (2016). Federal government announces contact line other for whistleblowers. The Nation newspaper, $23^{\text {rd }}$ December, 2016. Available from: www. thenation.net/fed-govt-announces-contact-line-others-whistleblowers/ [Accessed 20th May 2017].

Cistematix (2011). Industry analysis of the Nigerian mobile technology development. Available from: http://gsl.mit.edu/media/programs/nigeriasummer-2011/materials/cistematix_industry_analysis_of_the_nigerian_mobile_ technology.pdf

ELANGOVAN, R. \& ARUCHELVAN, S. (2013). A study of the role mobile phone communication tuberculosis DOTS treatment. Indian Journal of Community Medicine, 38(4), pp. 229-233.

Ericson (2016). Ericsson mobility report: Sub-Saharan Africa, Stockholm, Ericsson. 
Glo supports government cashless payment solution, mCash. Guardian newspaper, $30^{\text {th }}$ November 2016. Available from: http://m.guardian.ng/businessservices/glo-supports-government-cashless-payment-solution-mcash/ [Accessed $20^{\text {th }}$ May 2017].

Etisalat set to boost e-learning in Nigeria. IT News Africa, $4^{\text {th }}$ July 2016. Available from: http://www.itnewsafrica.com/2016/07/etisalatsettoboostelearninginnigeria/ [Accessed 20 $0^{\text {th }}$ May 2017].

KREUTZER, T. (2008). Assessing cell phone usage in a south African township school. Emerge 2008, July 7-18, Cape Town, South Africa. Available from: http:// emerge.uct.ac.za/emaerge2008.net/access/content/group/emerge2008/ presentationFiles/kreutzer/Cell\%20Phone\%20Usage.pdf

LISA (2015). The importance of cell phones in modern society. Electronic Sallin 1, $30^{\text {th }}$ December 2015. Available from: http://electronicsallin1.com/?p=321 [Accessed 15 ${ }^{\text {th }}$ August 2016].

National bureau of statistics (2006). The Nigerian statistical fact sheets on economic and social development. Federal Republic of Nigeria.

NCC to assist in rebuilding telecoms facilities in North East. Daily Trust Newspaper, $6^{\text {th }}$ March 2017. Available from: http://dailytrust.com.ng/news/business/ncc-to-assistin-rebuilding-telecoms-facikities-in-n-east/187974.html [Accessed 21 ${ }^{\text {st }}$ May 2017].

NDUKWE, C. (2005). From market liberalization to competition management: An update on the regulatory environment for investment. CWC's fourth international strategic conference on opportunities and investment in Nigeria's telecommunication sector, Abuja.

Nigerian communication commission (2016). Industry information. Available from: www.ncc.ng/index.php?option $=$ com_content\&view $=$ category\&id $=65 \&$ lte mid $=67$ [Accessed $13^{\text {th }}$ August 2016].

Nigeria's fibre optic cables still underutilised - Opeke. Nigerian Muse, $31^{\text {st }}$ December 2012. Available from: http://www.nigerianmuse.com/20121231040737zg/nmprojects/telecomproject/nigerias-fibre-optic-cables-still-under-utilised-opekemain-one/ [Accessed 20 $0^{\text {th }}$ May 2017].

ODUKOYA, T. I \& NKADI, M. (2008). MTN Nigeria: Analysis of the viability of offering. Lagos, UBA Global Markets.

OJEME, V. (2011). North has the highest rate of poverty - report. Vanguard Newspaper, $14^{\text {th }}$ September 2011. Available from: www.vanguardngr.com/2011/09/ north-has-the-highest-rate-of-poverty-rport/ [Accessed 20th March 2017].

OKONJI, E. (2017). GSMA: Mobile technology will drive digital transformation in Africa. Nigeria Today, $26^{\text {th }}$ January 2017. Available from: http://www.nigeriatoday.ng/ 2017/01/gsma-mobile-technology-will-drive-digital-transformation-in-africa/ [Accessed 20 $0^{\text {th }}$ May 2017]. 
OKUNOLA, F. (2016). Telecom company's 4G LTE service is live in Nigeria. Pulse Nigeria, $6^{\text {th }}$ October 2016. Available from: http://www.pulse.ng/tech/mtn-telecomcompanys-4g-lte-service-is-live-in-nigeria-id5574059.html [Accessed 20th May 2017].

ROGERS, E. M. (2003). Diffusion of innovations. New York, Free Press.

The violent road: Nigeria's North East. AOAV and NWGAV, $12^{\text {th }}$ December 2013. Available from: https://.aoav.org.uk/2013/the-violent-road-nigeria-north-east/

Top 5 4G LTE broadband providers in Nigeria. Nigerian Bulletin, 25 ${ }^{\text {th }}$ Februry, 2016. Available from: https://www.nigerianbulletin.com/threads/top-5-4g-ltebroadband-providers-in-nigeria.122470/ [Accessed 20 $0^{\text {th }}$ May 2017].

WILSON, J. \& GAPSISO, N. D. (2014). ICT, democracy and human rights in Nigeria. In: A. M. Solo, Handbook of research on political activism in the information age, 1 ed. Hershey, PA, IGI Global.

WILSON, J. \& GAPSISO, N. D. (2014). Market women and the mobile phone in Nigeria. Media and Communication, 1(2), pp. 59-70.

WILSON, J. \& GAPSISO, N. D. (2017). Communicating in the absence of mobile telephone network during the state of emergency in Borno state, Nigeria. World of Media, 2017, ISSN 2307-1605, pp. 143-167.

WILSON, J., LAWAN, A. K., \& JIBRIN, R. (2016). An analysis of the role of ICT in the 2015 general election in Borno state Nigeria. Journal of Social and Management Sciences, 2(2), pp. 41-54. 